\title{
METAL OPERATOR MINING FACTS - 2004
}

In 2004, a total of 251 metal mining operations reported employment to the Mine Safety and Health Administration (MSHA). Metal mines were the smallest mining commodity sector, comprising 1.7\% of all mining operations.

- Gold mines comprised $47.0 \%(\mathrm{n}=118)$ of all metal mining operations. Other common types of metal mines were iron ore $(\mathrm{n}=29 ; 11.6 \%)$, copper ore $(\mathrm{n}=27 ; 10.8 \%)$, and lead and/or zinc ore $(\mathrm{n}=18 ; 7.2 \%)$.

- Nevada had the largest number of metal mines $(\mathrm{n}=51 ; 20.3 \%)$, followed by Alaska $(\mathrm{n}=26$; $10.4 \%)$.

A total of 25,205 employees, ${ }^{1}$ corresponding to 26,091 full-time equivalent (FTE) ${ }^{2}$ employees, were reported by metal mine operators.

- Within the mining sectors, ${ }^{3}$ metal mine operator employees accounted for $9.6 \%$ of all employee hours reported to MSHA.

- Metal operator employee hours were reported for both underground (14.6\%) and surface (85.4\%) work locations. ${ }^{4}$

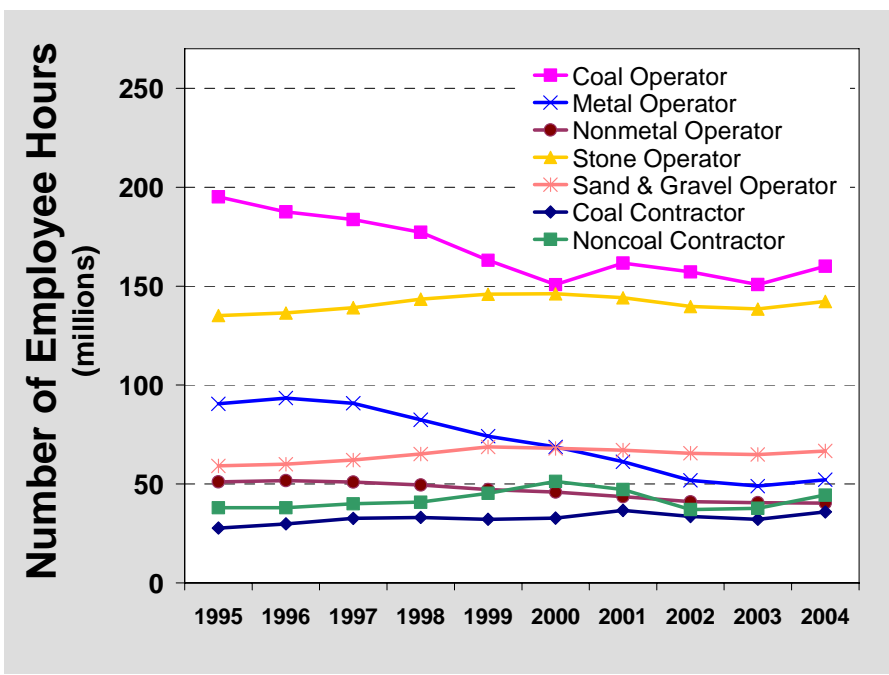

Two occupational fatalities occurred among metal mine operator employees in 2004, compared to one fatality in 2003.

- The metal mine operator fatality rate was 7.7 fatalities per 100,000 FTE employees.

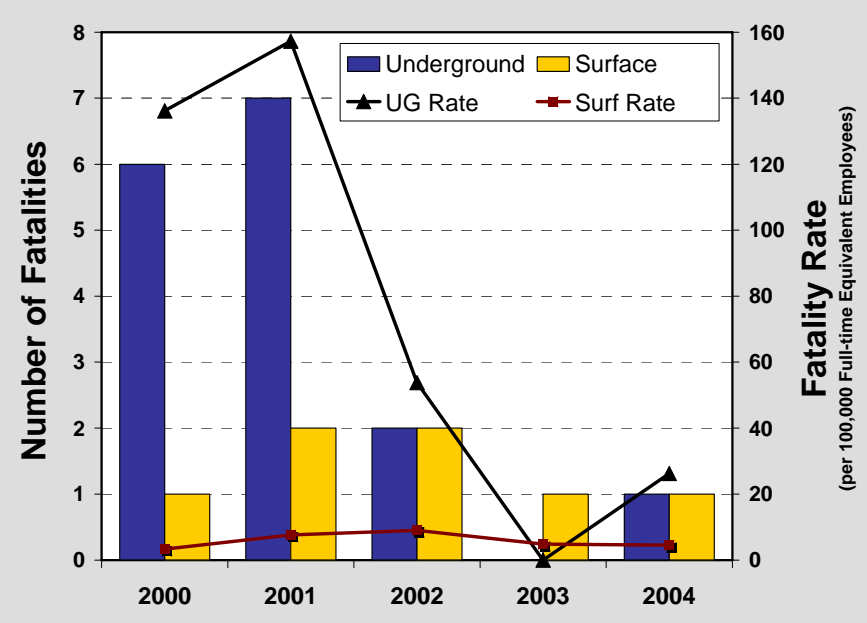

There were 558 nonfatal lost-time injuries (130 at underground and 428 at surface work locations) among metal operator employees occurring at a rate of 2.1 injuries per 100 FTE employees. A total of 27,057 days lost $^{5}$ from work resulted from these injuries.

- The underground nonfatal lost-time injury rate was greater than the surface injury rate (3.4 vs. 1.9 per $100 \mathrm{FTE}$ workers).

- The most frequent classification of nonfatal losttime injuries for metal operator employees involved handling materials ( $\mathrm{n}=206$; 36.9\%).

- Sprains and strains were the most frequently reported nature of injury ( $\mathrm{n}=260 ; 46.6 \%)$.

- The back was the most frequently reported part of the body injured $(\mathrm{n}=102 ; 18.3 \%)$ and accounted for 4,051 days lost from work.

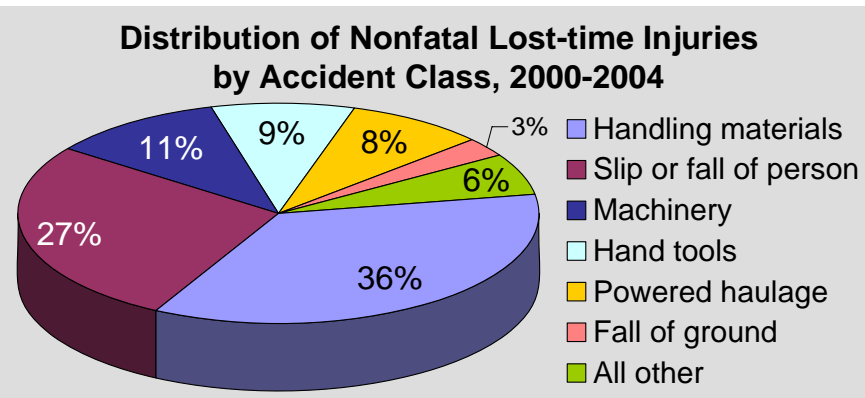

Note: "Fall of ground" includes MSHA's Accident/Injury/lllness classification for fall of face, rib, pillar, side, or highwall (from in place); fall of roof, back, or brow (from in place); and underground machinery cases when the source of injury was caving rock, coal, ore, or waste.

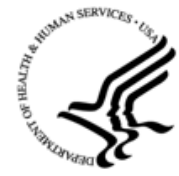


In 2004, 44 cases of occupational illnesses were reported to MSHA by metal operators. ${ }^{6}$ This compares to 63 cases reported in 2003.

- Joint, tendon, or muscle inflammation or irritation accounted for the most frequently reported occupational illnesses $(n=29 ; 65.9 \%)$.
- There were seven cases of hearing loss or impairment reported to MSHA (or 15.9\% of all occupational illnesses reported).

- Metal mining operations reported two cases of heat stroke, sunstroke, heat cramps, etc., accounting for $4.5 \%$ of all reported occupational illnesses in 2004.

\begin{tabular}{|c|c|c|c|c|c|c|}
\hline \multicolumn{7}{|c|}{ Mining Characteristics, 2004} \\
\hline $\begin{array}{l}\text { Commodity and } \\
\text { Type of Employer }\end{array}$ & $\begin{array}{l}\text { No. of } \\
\text { Mines }\end{array}$ & $\begin{array}{c}\text { No. of } \\
\text { Companies }\end{array}$ & $\begin{array}{c}\text { No. of } \\
\text { Employees }\end{array}$ & $\begin{array}{l}\text { No. of FTE } \\
\text { Employees }\end{array}$ & $\begin{array}{l}\text { Fatality } \\
\text { Rate }\end{array}$ & $\begin{array}{l}\text { Nonfatal } \\
\text { Lost-time } \\
\text { Injury Rate }\end{array}$ \\
\hline Coal Operator & 2,011 & -- & 73,024 & 80,069 & 28.7 & 3.9 \\
\hline Metal Operator & 251 & -- & 25,205 & 26,091 & 7.7 & 2.1 \\
\hline Nonmetal Operator & 741 & -- & 19,432 & 20,183 & 5.0 & 2.7 \\
\hline Stone Operator & 4,401 & -- & 68,417 & 71,153 & 11.2 & 3.2 \\
\hline Sand and Gravel Operator & 7,074 & -- & 37,000 & 33,364 & 24.0 & 2.3 \\
\hline Operator Total & 14,478 & -- & 223,078 & 230,860 & 18.2 & 3.2 \\
\hline Coal Contractor & -- & 2,550 & 30,228 & 17,964 & 27.8 & 2.6 \\
\hline Noncoal Contractor & -- & 4,143 & 42,511 & 22,198 & 36.0 & 1.7 \\
\hline Contractor Total & -- & 6,693 & 72,739 & 40,162 & 32.4 & 2.1 \\
\hline TOTAL & & & 295,817 & 271,022 & 20.3 & 3.0 \\
\hline
\end{tabular}

Data may not add to totals due to independent rounding. Number of employees was rounded at the subunit level of each mine to be consistent with MSHA reporting. Fatality rates were computed per 100,000 FTE employees. Nonfatal lost-time injury rates were computed per 100 FTE employees.

Data source: Publicly released files of employment and accident/injury/illness data collected by MSHA under 30 CFR 50.

Notes: All analyses exclude office employees, except for the total number of mining operations. Further statistical methodology is available on the NIOSH Internet [http://www.cdc.gov/niosh/mining/statistics/method.htm].

${ }^{1}$ Number of employees is the average number of persons working at individual establishments during calendar quarters of active operations. Employment numbers were rounded at the subunit level of each mine to be consistent with MSHA reporting.

${ }^{2}$ Full-time equivalent employees were computed using reported employee hours $(2,000$ hours $=1$ FTE $)$.

${ }^{3}$ Mining sectors: coal operators, metal operators, nonmetal operators, stone operators, sand and gravel operators, coal contractors, and noncoal contractors.

${ }^{4}$ Surface work locations include surface operations at underground mines (surface shops and yards, tipple physically located at the mine site), surface operations (strip or open pit mines including associated shops and yards), dredge (mining operations conducted from a platform floating on water), other surface operations (brine pumping, etc.), independent shops and yards not associated with a specific mine, and mill or preparation plant.

${ }^{5}$ Includes actual days away from work and/or days of restricted work activity. For permanently disabling injuries only, statutory days charged by MSHA were used if they exceeded the total lost workdays.

${ }^{6}$ Because of the complexity of attributing disease causation to the workplace, occupational illnesses may be underreported.

To receive NIOSH documents or for more information about occupational safety and health topics, contact $\mathrm{NIOSH}$ at

1-800-CDC-INFO (1-800-232-4636)

1-888-232-6348 (TTY)

e-mail: cdcinfo@cdc.gov

or visit the NIOSH Web site at http://www.cdc.gov/niosh

DHHS (NIOSH) Publication No. 2007-168 